\title{
PENGARUH MODEL PEMBELAJARAN MAKE A MATCH TERHADAP KREATIVITAS MENGGAMBAR PETA SISWA MI
}

\author{
Risma Dwi Arisona ${ }^{1}$, Athifa Megaratri Kumala ${ }^{2}$ \\ ${ }^{I}$ Jurusan Tadris Ilmu Pengetahuan Sosial, Institut Agama Islam Negeri Ponorogo, Indonesia \\ ${ }^{2} J u r u s a n$ Pendidikan Guru Madrasah Ibtidaiyah, Institut Agama Islam Negeri Ponorogo, Indonesia \\ arisona@iainponorogo.ac.id
}

Naskahditerima:24 September, 2020, direvisi: 28 desember, 2020, diterbitkan: 31 Maret, 2021

\begin{abstract}
This article aims to determine the effect of the make a match learning model on the creativity of drawing maps on the material of ethnic and cultural diversity in Indonesia. This study hypothesizes that there is a significant effect of the make a match learning model on the creativity of drawing maps of Madrasah Iibtidaiyah (MI)/ Primary School students. The article was conducted using a quasi-experimental research design. The research was carried out from January to February 2020 at MI Ma'arif Ngrupit Jenang Ponorogo-East Java Indonesia. The study population was MI students in class V and the research sample of students in the class VA were 26 students as the control class and class VB as many as 26 students as the experimental class. Techniques for collecting data on student creativity through drawing a map was test and observation. The data analysis used was the $\mathrm{t}$-test. The t-test results show the results of calculations using the $95 \%$ confidence level that the Pvalue $=0.0023<0.05$ indicates that the hypothesis is accepted. Based on the results of the data analysis, it is concluded that the learning model makes a match that $\mathrm{h}$ affects the creativity of drawing maps of MI students.
\end{abstract}

Keywords: Make a match; Madrasah Ibtidaiyah; Children creativity, Learning activity

\begin{abstract}
ABSTRAK
Artikel ini bertujuan untuk mengetahui bagaimana pengaruh model pembelajaran make a match terhadap kreativitas menggambar peta pada materi keragaman suku bangsa dan budaya di Indonesia. Hal ini disesuaikan dengan keunggulan dari model pembelajaran make a match dimana salah satu keunggulan tersebut adalah dapat meningkatkan kreativitas siswa dalam menggambar peta. Adapun hipotesis dari penelitian ini adalah adanya pengaruh yang signifikan dari model pembelajaran make a match terhadap kreativitas menggambar peta siswa MI. Penelitian ini dilakukan dengan menggunakan rancangan penelitian ekperimen kuasi (Quasi Experimental Design). Pelaksanaan penelitian dilaksanakan pada bulan Januari sampai Februari Tahun 2020 di MI Ma'arif Ngrupit Jenangan Ponorogo Jawa Timur Indonesia. Populasi dalam penelitian ini adalah siswa kelas tinggi yaitu kelas $\mathrm{V}$ dan sampel penelitiannya adalah siswa kelas VA sebanyak 26 siswa sebagai kelas kontrol dan siswa kelas VB sebanyak 26 siswa sebagai kelas eksperimen. Teknik pengumpulan data dalam penelitian ini adalah tes berupa lembar tes kreatifitas dan observasi. Analisis data yang digunakan pada penelitian adalah uji-t. Hasil uji-t dikemukakan hasil perhitungan dengan menggunakan taraf kepercayaan 95\% bahwa nilai $P$ value $=0.0023<0.05$ menunjukkan bahwa hipotesis diterima. Berdasarkan hasil analisis data tersebut, diperoleh simpulan bahwa model pembelajaran make a match berpengaruh terhadap kreativitas menggambar peta siswa MI.
\end{abstract}

Kata Kunci: Make a match; Madrasah Ibtidaiyah; Kreativitas anak; Aktivitas pembelajaran 


\section{Pendahuluan}

Pembelajaran Ilmu Pengetahuan Sosial merupakan salah satu mata pelajaran yang diberikan di SD/MI dengan mengkaji seperangkat peristiwa, konsep, generalisasi dan fakta (Siska, 2016). Materi yang diajarkan di sekolah dalam pembelajaran Ilmu Pengetahuan Sosial di sekolah dasar khususnya pada kelas $\mathrm{V}$ adalah materi keragaman suku bangsa dan budaya di Indonesia. Materi tersebut, terdapat banyak konsep dan pelajaran yang harus dipahami dan dimengerti siswa.

Pada kenyataannya dalam melaksanakan pembelajaran mata pelajaran Ilmu Pengetahuan Sosial (IPS) di madrasah ibtidaiyah, terindikasi bahwa proses pembelajaran di kelas cenderung teks book oriented. Hal ini berarti guru hanya memindahkan pengetahuan umum secara utuh kepada siswa. Guru hanya fokus menghabiskan materi pelajaran dari buku teks. Guru juga cenderung menggunakan metode ceramah, sehingga kurang menarik dalam pembelajaran materi ini. Akibatnya, siswa kurang diberi kesempatan untuk mengembangkan kreativitas saat proses pembelajaran dan tidak bersemangat, sehingga pembelajaran terkesan membosankan (Muchtar, 2004).

Pembelajaran yang membosankan akan menciptakan suasana belajar yang tidak menyenangkan. Akibatnya, siswa menjadi tidak termotivasi untuk belajar lebih giat lagi. Motivasi belajar merupakan suatu dorongan yang ada pada diri seseorang individu untuk melaksankan sesuatu guna mencapai tujuan dari belajar itu sendiri (Emda, 2018). Motivasi yang rendah akan mempengaruhi kreativitas siswa.

Hasil pengamatan yang dilaksanakan pada tanggal 13 Januari 2020 di MI Ma'arif Ngrupit Jenangan Ponorogo, ada beberapa hal yang menyebabkan rendahnya kreativitas siswa dalam menggambar peta pada mata pelajaran IPS, diantaranya: 1) pembelajaran yang monoton yang tidak menerapakan model pembelajaran yang inovatif, sehingga siswa malas mengikuti kegiatan belajar; 2) saat pembelajaran siswa hanya mendengar dan mencatat apa yang disampaikan guru, sehingga tidak ada dorongan untuk antusias dalam mengikuti pembelajaran dan kurang memperhatikan instruksi dari guru; 3) kurangnya kerjasama siswa dalam kelompok, sehingga hanya satu orang yang mngerjakan tugas diberikan dan akhirnya tugas dikerjkan dengan asal-asalan; dan 4) Aktivitas belajar yang membosankan membuat kreativitas siswa rendah.

Jika guru cenderung hanya mengajar dengan apa adanya dengan cara yang seadanya, maka proses pembelajaran akan menjadi membosankan, bahkan pembelajaran dapat dinyatakan tidak berhasil. Mengajar sama halnya dengan pembuatan keputusan yang perlu diagnosa yang baik. Oleh karena itu seorang pengajar harus memperhatikan benar apa diagnosa yang penting dalam mengajar, bukan hanya mengajar dijadikan sebagai kegiatan yang rutin di kelas (Wahab, 2012).

Pola pembelajaran yang hanya sebagai kegiatan rutin dapat menyebabkan siswa kurang berkonsentrasi. Hal ini, dapat membuat pembelajaran kurang digemari oleh sebagian siswa. Mata pelajaran Ilmu Pengetahuan Sosial terkesan kurang menarik disebabkan ruang lingkup pelajaran yang luas (Siska, 2016). Siswa menganggap mata pelajaran Ilmu Pengetahuan Sosial adalah pelajaran yang monoton dan kurang adanya bervariasi, diperparah dengan metode guru yang mengajarkan pembelajaran terlalu teoritis pada buku. Padahal, kreativitas penting dipahami bagi guru dalam kaitannya dengan tugas dan tanggung jawab sebagai pendidik.

Kreativitas berhubungan erat dengan proses berpikir. Seseorang akan dapat berimajinasi dengan baik bila mempunyai kreativitas yang baik pula. Siswa yag kreatif akan mempunyai rasa ingin tau yang tinggi, memiliki rasa percaya diri dan memiliki kegemaran yang kreatif. Ciri kreatif lainnya, antara lain siswa mempunyai prakarsa,minat 
luas, mandiri dalam berpikir, melit (ingin tahu), senang berpetualang, penuh energi, percaya diri, bersedia mengambil resiko, dan berani dalam pendirian dan keyakinan (Munandar, 2014).

Kemampuan berfikir kreatif sebenarnya dapat ditingkat hingga ke tingkat yang tinggi (Yuliana, 2015). Caranya dengan melakukan pemahaman proses berfikir beserta faktornya. Oleh karena itu dapat disimpulkan bahwa tingkatan seseorang dalam berfikir kreatif dapat berubah sampai tingkat berikutnya. Misalnya, kegiatan pembelajaran guru bersama siswa yang dapat mengasah kreativitas siswa. Tidak hanya terpaku dengan buku dan hafalan yang monoton. Tentunya, kegiatan pembelajaran didukung oleh kemampuan guru dalam memvariasikan kegiatan pembelajaran agar tujuan pembelajaran dapat tercapai dan terlaksana dengan baik.

Mengembangkan kreativitas siswa pasti mengalami berbagai hambatan bahkan dapat mematikan kreativitasnya. Hambatan-hambatannya yaitu evaluasi, hadiah, persaingan dan lingkungan yang membatasi. Peran guru dan orang tua juga berpegaruh terhadap faktor penghambat kreativitas. Penghambat lainnya yaitu siswa tidak berani untuk terampil dan mengembangkan kreativitasnya (Munandar, 2014). Agar proses belajar mengajar mata pelajaran Ilmu Pengetahuan Sosial dapat berkembang sesuai dengan hakikat Ilmu Pengetahuan Sosial, maka diperlukan adanya model pembelajaran yang sesuai. Oleh karena itu, cara untuk mengatasi sebuah permasalahan kreativitas, salah satu model pembelajaran yang dapat dijadikan solusi dalam persoalan tersebut yakni model pembelajaran make a match.

Model pembelajaran kooperatif bukan hanya sekedar belajar di dalam kelompok, melaikan kelompok kooperatif didasarkan pada tanggung jawab setiap individu. Diwajibkan semua individu bekerja sama untuk mencapai tujuan dari kelompoknya. Membagi siswa dalam kelompok, tidak langsung disebut sebagai kelompok kooperatif, melainkan pembagian kelompok kooperatif hanya diatur oleh seorang guru saat pembelajaran (Huda, 2013).

Pengertian model pembelajaran make a match ialah salah satu dari model pembelajaran kooperatif dengan ciri utama, yakni siswa diminta untuk mencari pasangannya dari kartu yang merupakan "jawaban" atau "pertanyaan" dari materi yang sudah ditentukan oleh guru dalam proses pembelajaran. Model pembelajaran make a match merupakan model pembelajaran dengan siswa mencari pasangannya untuk mempelajari hakikat konsep dengan suasana yang menyenangkan. Dikembangkan oleh Lorna Curran yang dapat diaplikasikan untuk semua mata pelajaran dan semua jenjang kelas (Huda, 2013).

Langkah-langkah penerapan model pembelajaran tipe make a match yaitu guru menyiapkan kartu yang berisi soal dan jawaban sesuai dengan topik, masing-masing siswa mendapat bagian kartu yang berisi soal/jawaban, siswa memikirkan soal/jawaban yang diperoleh, siswa menyocokkanpasangan yang cocok dengan soal atau jawaban yang diperoleh dengan memberikan waktu, apabila siswa tidak sesuai mencocokkan dikenai hukuman sesuai dengan kesepakatan, setelah selesai satu babak acak lagi kartu sehingga siswa mendapatkan kartu soal/jawaban lain, siswa bersama guru membuat kesimpulan terhadap materi pembelajaran (Fathurrohman, 2017). Pada pelaksaanaanya langkahlangkah kegiatan pemnbelajaran dapat dikembangkan oleh guru sesuai dengan kebutuhan masing-masing.

Pada umumnya model ini lebih digunakan untuk melihat hasil belajar siswa. Disini peneliti akan melihat bagimana pengaruh model pembelajaran make a match terhadap kreativitas menggambar peta sesuai dengan keunggulan yang dimiliki model ini. 
Keunggulan model pembelajaran ini adalah siswa mencari pasangan sambil belajar mengenai suatu konsep atau topik dalam suasana belajar yang menyenangkan. Karakteristik model pembelajaran make a match mempunyai hubungan erat terhadap karakteristik siswa yang suka bermain dan dapat menumbuhkan kreativitas terhadap siswa.

Berdasarkan penelitian terdahulu menunjukkan adanya pengaruh model pembelajaran make a match terhadap kreativitas. Diketahui dari beberapa hasil penelitian terdahulu yang menyatakan bahwa model pembelajaran make a match berpengaruh positif terhadap kreativitas siswa (Afiatun, 2013); (Zakiah \& Kusmanto, 2017); (Cahyani, Astuti, dan Suryanto, 2017); (Dediansyah, Akhyar, dan Musadad, 2015), (Nurmanika \& Rif'at, 2015), dan (Hamid, 2018). Hal tersebut mendukung hipotesis penelitian ini bahwa ada pengaruh yang signifikan model pembelajaran tipe make a match terhadap kreativitas manggambar peta siswa MI.

Akan tetapi, berdasarkan analisis penelitian terdahulu terdapat juga kekurangan dari model pembelajaran make a match yang dapat diantisipasi dalam pelaksanaan penelitian ini. Seperti, kesulitan membuat kartu menarik dan sulit mengonsentrasikan siswa karena pembelajaran ini terkesan seperti permainan. Untuk itu, dalam penelitian ini kartu dibuat oleh siswa sendiri, sehingga akan memacu kreativitas anak. Selain itu, untuk mengarahkan konsentrasi siswa, guru harus memberikan instruksi yang jelas dalam melaksanakan pembelajaran ini.

Berdasarkan uraian tersebut, model pembelajaran tipe make a match diharapkan sesuai dengan tujuan pembelajaran dan mewujudkan suatu pembelajaran yang bermakna serta dapat meningkatkan kreativitas siswa menggambar peta mata pelajaran Ilmu Pengetahuan Sosial materi keragaman suku bangsa dan budaya di Indonesia. Berdasarkan latar belakang yang telah diuraikan, tujuan penelitian ini adalah untuk mengetahui pengaruh model pembelajaran make a match terhadap kreativitas menggambar peta siswa MI.'Tujuan penelitian ini adalah untuk mengetahui pengaruh model pembelajaran make a match terhadap kreativitas menggambar peta siswa MI. Ruang lingkup penelitian ini membahas tentang ada tidaknya pengaruh model pembelajaran make a match terhadap kreativitas menggambar peta siswa MI yang dilaksanakan pada siswa kelas lima pada materi keragaman suku bangsa dan budaya di Indonesia.

\section{Metode Penelitian}

Penelitian ini menggunakan pendekatan kuantitatif dengan jenis Quasi Eksperimen design. Quasi eksperimental design yaitu desain yang mempunyai kelompok kontrol yang tidak dapat sepenuhnya mengontrol variabel-variabel luar yang mempengaruhi pelaksanaan eksperimen (Sugiyono, 2015). Pembelajaran dengan model pembelajaran kooperatif tipe make a match pada penelitian ini dilaksanakan pada kelas VA dan VB MI Ma'arif Ngrupit Jenangan Ponorogo. Materi pokok yang dipelajari adalah keragaman suku bangsa dan budaya di Indonesia.Desain penelitian eksperimen kuasi dirancang untuk mengetahui pengaruh model pembelajaran make a match terhadap kreativitas menggambar peta siswa MI. Berikut gambar desain penelitian ini.

$\mathrm{X} 1 \mathrm{X} \longrightarrow \mathrm{Y}$
$\mathrm{X} 2 \longrightarrow \mathrm{Y}$

\section{Gambar 1. Desain Penelitian}

Sumber: Sugiyono, 2015

Keterangan:

$\mathrm{X} 1=$ pembelajaran dengan make a match(kelas eksperimen) 
$\mathrm{X} 2=$ Pembelajaran konvensional dengan ceramah (kelas kontrol)

$\mathrm{Y}=$ Hasil kreativitas menggambar peta

Proses pembelajaran model pembelajaran make a match dalam penelitian ini dilaksanakan selama dua kali pertemuan dengan masing-masing pertemuan berlangsung selama 2x35 menit. Siswa diminta untuk menggambar peta Indonesia sesuai dengan kreativitas masing-masing dari pertanyaan yang diberikan oleh guru.

Tahap penilaian kreativitas melalui siswa diminta untuk menggambar peta Indonesia secara berkelompok di kertas gambar yang disediakan oleh guru. Gambar tersebut juga di warnai oleh siswa dan setiap kelompok berdiskusi untuk menempelkan suku bangsa dan tarian daerah yang sesuai pada pulau yang digambar oleh masing-masing kelompok. Setelah itu masing-masing kelompok mempresentasikan di depan kelas. Guru menilai kreativitas siswa dengan melihat aspek-aspek yang dinilai yaitu kejelasan menyajikan gambar dengan maksud kesesuaian gambar dengan soal yang dijawab, kerapian dalam menggambar dengan maksud menggambar dengan rapi dan jelas, mengidentifikasi keragaman suku bangsa dan budaya dengan maksud kesesuaian siswa dalam menempelkan suku bangsa dan tarian di masing-masing pulau, dan kelengkapan komponen peta dengan maksud peta yang digambar siswa harus memenuhi komponen kelengkapan peta.

Kreativitas diukur dengan siswa menggambar "Peta Indonesia" dengan membentuk siswa menjadi 5 kelompok, yaitu menggambar pukul Jawa, Sumatra, Kalimantan, Sulawesi, dan Papua. Menggambar dengan memperhatikan kejelasan gambar dan kesesuaian gambar dengan pertanyaan yang diberikan kepada guru. Sistem penilaian kreativitas dilaksanakan secara berkelompok yang dibentuk melalui acak. Menggambar yang dilakukan pada buku gambar serta mewarnai dan memberikan keterangan pada pulau yang akan di gambar.

Teknik pengumpulan data dalam penelitian ini diperoleh melalui lembar penilaian kreativitas berupa menggambar peta Indonesia bersama kelompok, kemudian diminta untuk menempelkan suku bangsa dan budaya Indonesia pada peta Indonesia yang sudah dibuat secara berkelompok. Penelitian ini difokuskan pada kegiatan setiap perwakilan kelompok mengambil satu pertanyaan, kemudian setiap kelompok diminta untuk menggambar sesuai dengan kreativitasnya jawaban dari pertanyaan tersebut yang diarahkan pada menggambar peta Indonesia.

Data kreativitas menggambar peta siswa diperoleh melalui lembar penilaian kreativitas selama pembelajaran berlangsung pengamatan dilakukan dengan cara menilai hasil kreativitas menggambar peta yang dilakukan siswa. Kemudian hasil dari lembar penilaian digunakan untuk mengetahui kreativitas menggambar peta yang akan digunakan untuk pengujian hipotesis. Uji hipotesis penelitian ini menggunakan t-test dengan menggunakan Ms. Excel. Berikut tabel 1, tentang penjabaran aspek-aspek yang dinilai dalam lembar penilaian kreativitas menggambar peta siswa MI.

Tabel 1. Aspek-Aspek yang Dinilai dalam Kreativitas Menggambar Peta

\begin{tabular}{|ll|l|c|}
\hline \multicolumn{2}{|c|}{ Aspek yang dinilai } & \multicolumn{1}{|c|}{ Butir yang dinilai } & Pedoman Penilaian \\
\hline $\begin{array}{l}\text { Kejelasan menyajikan } \\
\text { gambar }\end{array}$ & $\begin{array}{l}\text { Kesesuaian antara } \\
\text { gambar dengan soal } \\
\text { yang dijawab }\end{array}$ & 20 \\
\hline 2. & $\begin{array}{l}\text { Kerapian dalam } \\
\text { menggambar }\end{array}$ & $\begin{array}{l}\text { Menggambar dengan } \\
\text { rapi dan jelas dalam }\end{array}$ & 20 \\
\hline 3. & $\begin{array}{l}\text { Mengidentifikasi } \\
\text { keragaman suku }\end{array}$ & $\begin{array}{l}\text { Kejelasan } \\
\text { mengidentifikasi }\end{array}$ & 20 \\
\hline
\end{tabular}




\begin{tabular}{|l|l|c|}
\hline Aspek yang dinilai & \multicolumn{1}{|c|}{ Butir yang dinilai } & Pedoman Penilaian \\
\hline $\begin{array}{l}\text { bangsa dan budaya di } \\
\text { Indonesia }\end{array}$ & $\begin{array}{l}\text { keragaman suku } \\
\text { bangsa dan budaya di } \\
\text { Indonesia }\end{array}$ & \\
\hline $4 . \quad$ Kelengkapan Peta & $\begin{array}{l}\text { Kelengkapan peta } \\
\text { meliputi judul, skala, } \\
\text { orientasi, simbol, } \\
\text { warna, lettering, } \\
\text { gratikul, inset, garis } \\
\text { tepi, legenda, sumber } \\
\text { dan tahun pembuatan. }\end{array}$ & 20 \\
\hline
\end{tabular}

\section{Hasil dan Diskusi}

Uji prasyarat dilakukan sebelum uji hipotesis, yaitu data nilai kreativitas menggambar peta di uji normalitas dan homogenitas. Berdasarkan hasil uji normalitas dan homogenitas data terdistribusi normal dan homogen. Hal tersebut berdasarkan dari uji normalitas yang menunjukkan data menyebar secara normal yaitu $(1.52)>(0.188)$ dilihat dari Tabel Kolmogorov-Smirnov. Hasil uji homogenitas yaitu $F_{\text {Hitung }}(0.407)<\mathrm{F}_{\text {Tabel }}$ (1.955) dan disimpulkan bahwa data menyebar secara normal dan memiliki variasi yang identik (homogen). Kemudian dilaksanakan uji hipotesis pengaruh model pembelajaran make a match terhadap kreativitas menggambar peta siswa MI. Hasil uji hipotesis dengan menggunakan Ms.Excel dapat dilihat dalam tabel 2 berikut ini.

Tabel 2. Hasil Uji-t

\begin{tabular}{|l|c|c|}
\hline & Eksperimen & Kontrol \\
\hline Mean & 93.653 & 89.192 \\
\hline Variance & 17.115 & 42.001 \\
\hline Observations & 26 & 26 \\
\hline Poled Variance & 29.558 & \\
\hline Hypothesized Mean Difference & 0 & \\
\hline Df & 50 & \\
\hline t Stat & 2,95 & \\
\hline P(T<=t) one-tail & 0.0023 & \\
\hline T Critical one-tail & 1.675 & \\
\hline
\end{tabular}

Sumber: Peneliti, 2020

Berdasarkan hasil uji-t dikemukakan hasil perhitungan bahwa nilai $P$ value $=$ 0.0023 dengan menggunakan taraf kepercayaan 95\%, taraf signifikansi kurang dari 0.05 yaitu $\mathrm{P}(0.0023)<(0.05)$. Hal tersebut menunjukkan bahwa hipotesis diterima, yaitu ada pengaruh model pembelajaran make a match terhadap kreativitas menggambar peta siswa MI.Temuan penelitian ini sejalan dengan penelitian sebelumnya yang menyatakan bahwa model pembelajaran make a match terhadap kreativitas siswa khususnya (Afiatun, 2013); (Zakiah \& Kusmanto, 2017); (Cahyani, Astuti, dan Suryanto, 2017); (Dediansyah, Akhyar, Musadad, 2015), (Nurmanika \& Rif'at, 2015), dan (Hamid, 2018).

Pada penelitian ini kreativitas mengarah pada menggambar peta yang dapat meningkatkan aktivitas siswa. Seiring dengan aktivitas yang meningkat kreativitas juga akan meningkat terutama dalam menggambar peta. Hal ini, sejalan dengan penelitian (Lestari, 2016) yang menyatakan bahwa dalam peningkatan aktivitas belajar siswa juga meningkatkan dalam pembuatan peta. 
Ada beberapa hal yang mempengaruhi perbedaan kualitas hasil dari kreativitas menggambar peta antara kelas eksperimen dan kontrol. Penggunaan model pembelajaran make a match membuat suasana pembelajaran menjadi menyenangkan, sehingga memacu siswa untuk mengembangkan kreativitasnya. Kreativitas tersebut tertuang di hasil gambar peta yang mereka hasilkan. Tidak heran gambar peta yang mereka buat memenuhi indikator penilaian yang maksimal. Hasil penilaian terkait kreativitas siswa pada kelas eksperimen dan kelas kontrol dapat ditunjukkan dengan tabel 3 hasil kreativitas menggambar peta sebagai berikut:

Tabel 3 Hasil Kreativitas Menggambar Peta Siswa MI

\begin{tabular}{|c|c|c|c|c|c|c|c|c|c|c|c|}
\hline \multicolumn{6}{|c|}{ Kelas Eksperimen } & \multicolumn{6}{|c|}{ Kelas Kontrol } \\
\hline \multirow{2}{*}{ No } & \multicolumn{4}{|c|}{ Aspek } & \multirow{2}{*}{ Jumlah } & \multirow{2}{*}{ No } & \multicolumn{4}{|c|}{ Aspek } & \multirow{2}{*}{ Jumlah } \\
\hline & $\mathrm{A}$ & B & $\mathrm{C}$ & D & & & $\mathrm{A}$ & B & $\mathrm{C}$ & $\mathrm{D}$ & \\
\hline 1 & 40 & 18 & 15 & 20 & 93 & 1 & 40 & 15 & 18 & 12 & 85 \\
\hline 2 & 40 & 15 & 20 & 15 & 90 & 2 & 40 & 20 & 16 & 20 & 96 \\
\hline 3 & 40 & 20 & 20 & 18 & 98 & 3 & 40 & 10 & 20 & 12 & 82 \\
\hline 4 & 40 & 18 & 20 & 15 & 93 & 4 & 40 & 20 & 20 & 15 & 95 \\
\hline 5 & 40 & 15 & 20 & 15 & 90 & 5 & 40 & 15 & 18 & 12 & 85 \\
\hline 6 & 40 & 15 & 20 & 15 & 90 & 6 & 40 & 12 & 18 & 12 & 82 \\
\hline 7 & 40 & 18 & 15 & 20 & 93 & 7 & 40 & 20 & 20 & 15 & 95 \\
\hline 8 & 40 & 18 & 20 & 15 & 93 & 8 & 40 & 10 & 20 & 12 & 82 \\
\hline 9 & 40 & 20 & 20 & 18 & 98 & 9 & 40 & 12 & 18 & 12 & 82 \\
\hline 10 & 40 & 18 & 15 & 20 & 93 & 10 & 40 & 20 & 16 & 20 & 96 \\
\hline 11 & 40 & 20 & 20 & 18 & 98 & 11 & 40 & 20 & 20 & 15 & 95 \\
\hline 12 & 40 & 20 & 20 & 18 & 98 & 12 & 40 & 20 & 20 & 15 & 95 \\
\hline 13 & 40 & 18 & 20 & 15 & 93 & 13 & 40 & 20 & 20 & 15 & 95 \\
\hline 14 & 40 & 20 & 20 & 18 & 98 & 14 & 40 & 10 & 20 & 12 & 82 \\
\hline 15 & 40 & 15 & 20 & 15 & 90 & 15 & 40 & 20 & 16 & 20 & 96 \\
\hline 16 & 40 & 15 & 20 & 15 & 90 & 16 & 40 & 20 & 16 & 20 & 96 \\
\hline 17 & 40 & 20 & 20 & 18 & 98 & 17 & 40 & 20 & 20 & 15 & 95 \\
\hline 18 & 40 & 20 & 20 & 18 & 98 & 18 & 40 & 12 & 18 & 12 & 82 \\
\hline 19 & 40 & 18 & 20 & 15 & 93 & 19 & 40 & 10 & 20 & 12 & 82 \\
\hline 20 & 40 & 18 & 20 & 15 & 93 & 20 & 40 & 15 & 18 & 12 & 85 \\
\hline 21 & 40 & 20 & 20 & 18 & 98 & 21 & 40 & 15 & 18 & 12 & 85 \\
\hline 22 & 30 & 15 & 20 & 15 & 80 & 22 & 40 & 20 & 16 & 20 & 96 \\
\hline 23 & 40 & 18 & 20 & 15 & 93 & 23 & 40 & 20 & 20 & 15 & 95 \\
\hline 24 & 40 & 20 & 20 & 18 & 98 & 24 & 40 & 10 & 20 & 12 & 82 \\
\hline 25 & 40 & 18 & 15 & 20 & 93 & 25 & 40 & 20 & 16 & 20 & 96 \\
\hline 26 & 40 & 18 & 15 & 20 & 93 & 26 & 40 & 12 & 18 & 12 & 82 \\
\hline \multicolumn{5}{|c|}{ Rata-rata } & 94 & \multicolumn{5}{|c|}{ Rata-rata } & 89 \\
\hline
\end{tabular}

Sumber: Peneliti, 2020 
Berdasarkan hasil penilaian kreativitas menggambar peta menunjukkan rata-rata nilai kelas eksperimen lebih tinggi daripada kelas kontrol. Rata-rata nilai kelas ekperimen sebesar 94, sedangkan kelas kontrol hanya sebesar 89. Besar kecilnya nilai rata-rata kreativitas dipengaruhi oleh besar kecinya nilai yang diperoleh dari hasil peta yang dibuat oleh siswa. Rata-rata kelas ekperimen lebih baik pada aspek B (kerapian dalam menggambar), $\mathrm{C}$ (mengidentifikasi keragaman suku bangsa dan budaya di Indonesia), dan D (kelengkapan peta) dibandingkan dengan kelas kontrol. Semakin baik peta yang dihasilkan dan cara menyajikannya akan mendapatkan nilai semakin tinggi. Berikut grafik rata-rata nilai kreativitas menggambar peta siswa MI.

Nilai Hasil Kreativitas Menggambar Peta

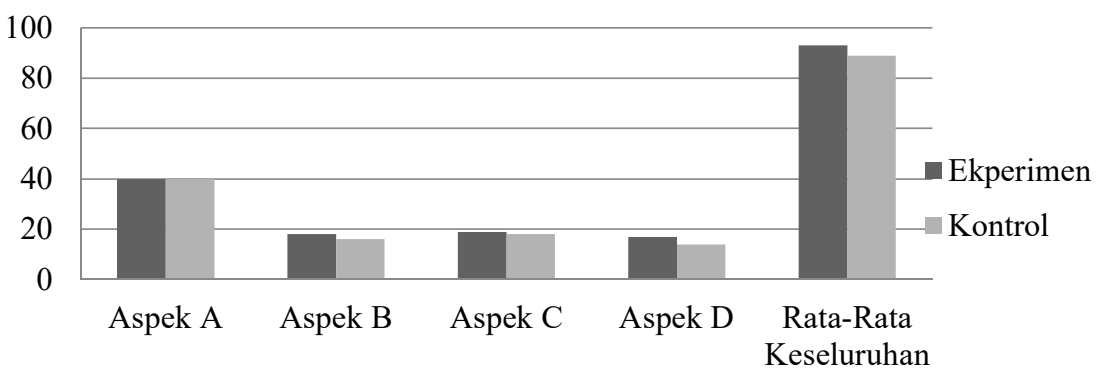

Gambar 1. Grafik Nilai Hasil Kreativitas Menggambar Peta Sumber: Peneliti, 2019.

Ada beberapa faktor yang menyebabkan nilai hasil kreativitas menggambar peta kelas eksperimen lebih tinggi dibanding kelas kontrol. Pertama, model pembalajaran make a match dalam penelitian ini adalah memasangkan gambar suku bangsa dan budaya pada peta Indonesia yang telah dibuat. Hal ini berarti siswa diajarkan untuk mengidentifikasi keragaman suku bangsa dan budaya Indonesia dengan pembelajaran yang menarik dan menyenangkan, sehingga siswa kelas eksperimen lebih memahami materi suku bangsa dan budaya di Indonesia. Akibatnya, pada penilaian aspek C (mengidentifikasi keragaman suku bangsa dan budaya di Indonesia) kelas esperimen mendapatkan nilai yang lebih tinggi.

Kedua, model pembalajaran make a match mendorong siswa untuk aktif mengikuti pembelajaran, sehingga ketika guru menugaskan untuk menggambar Peta Indonesia siswa aktif melaksanakannya. Keaktifan siswa untuk mengikuti pentujuk tugas yang diberikan dalam pembuatan Peta Indonesia membuat kelas eksperimen menghasilkan peta yang lengkap komponennya, seperti peta dilengkapi judul, skala, orientasi, simbol, warna, lettering, gratikul, inset, garis tepi, legenda, sumber, dan tahun pembuatan. Selain itu, kerapian peta kelas eksperimen juga lebih baik. Hal tersebut dapat dilihat dari penilaian aspek B (kerapian dalam menggambar) dan D (kelengkapan peta) pada kelas ekperimen lebih tinggi daripada kelas kontrol. Dengan demikian, kelas dengan pembelajaran make a match menghasilkan peta yang lebih baik dibandingkan pembelajaran ceramah.

Ketiga, model pembalajaran make a match mendorong siswa untuk bekerjasama dengan teman sekolompoknya untuk menyelesaikan tugas yang diberikan guru. Ketika siswa mendapat tugas menggambar Peta Indonesia, siswa dengan senang hati bekerja sama untuk meyelesaikan tugas yang diberikan. Aktivitas menggambar peta dilaksanakan secara bersama, sehingga walaupun terlihat rumit mereka dapat menyelesaikan dengan baik dan mampu memasangkan gambar suku bangsa dan budaya sesuai daerah asalnya. Hal ini berarti model pembelajaran Make A Match dapat meningkatkan aktivitas siswa (Febriana, 2011). Aktivitas siswa meningkat akan berpengaruh pada kreativitas siswa. 
Tercapainya kreativitas menggambar peta yang maksimal dengan model pembalajaran make a match dalam penelitian ini, tidak terlepas dari peran guru. Selama pembelajaran, guru telah menunjukkan tindakan dan instruksi yang memang harus dilakukan dalam model pembalajaran make a match yang mengarah pada meningkatnya kreativitas menggambar peta. Guru telah menjadi fasilitator dengan menyediakan peralatan yang diperlukan untu menggambar peta, gambar suku bangsa dan budaya yang harus ditempel, dan lembar intruksi tugas menggambar peta yang harus dilakukan sesuai dengan tujuan pembelajaran. Siswa dapat mengeluarkan kreativitas yang dimiliki dalam menggambar peta, misalnya, melengkapi komponen peta, menggambar dengan rapi, dan mewarnai peta sesuai dengan intepretasinya.

\section{Kesimpulan}

Berdasarkan analisis data dan pembahasan dapat diambil kesimpulan bahwa model pembelajaran make a match berpengaruh terhadap kreativitas menggambar peta siswa MI pada materi keragaman suku bangsa dan budaya di Indonesia. Hal tersebut dapat dilihat dari hasil uji hipotesis yang menunjukkan nilai signifikansi $0.0023<0.05$ yang artinya hipotesis diterima. Selain itu, rata-rata hasil nilai kreativitas menggambar peta Indonesia yang dilaksanakan pada kelas eksperimen dan kelas kontrol menunjukkan nilai kelas eksperimen lebih unggul dibandingkan dengan nilai kelas kontrol. Ada beberapa faktor yang menyebabkan model pembelajaran make a match berpengaruh terhadap kreativitas menggambar peta siswa MI, yaitu: 1) mendorong kemampuan mengidentifikasi; 2) mendorong siswa untuk aktif mengikuti pembelajaran; dan 3) mendorong siswa untuk bekerjasama.

\section{Acknowledgment}

Peneliti ucapkan terimkasih kepada jajaran dekanat Fakultas Tarbiyah dan Ilmu Keguruan, jurusan Tadris IPS, dan Jurusan PGMI IAIN Ponorogo yang telah memberikan dukungan baik materi maupun non materi untuyk terlaksanakannya penelitian ini. Selain itu peneliti juga ucapakan terimaksih kepada kepala sekolah dan seluruh dewan guru MI Maarif Jenangan yang telah mengijinkan peneliti melaksanakan penelitian.

\section{Daftar Pustaka}

Afiatun, S. (2013). Penerapan Strategi Make a Match untuk Meningkatkan Kreativitas Belajar pada Mata Pelajaran IPS Siswa Kelas IV SDN 2 Keprabon Polanharjo Klaten Tahun 2012/2013. Universitas Muhammadiya Surakarta.

Cahyani, Made Ari Okta; Astuti, Ni Made Erpia Ordani; dan Suryanto, I. W. (2017). Penerapan Model Pembelajaran Make a Match pada Mata Pelajaran Boga Dasar Untuk Meningkatkan Kreativitas dan Hasil Belajar Siswa Kelas X. Media Edukasi:Jurnal Ilmu Pendidikan, 1(2), 96-106.

Dediansyah, Agus; Akhyar, M., \& Musadad, A. A. (2015). Perbedaan Pengaruh Model Pembelajaran Jigsaw dan Make A Match Terhadap Prestasi Belajar Sejarah Ditinjau dari Kreativitas Belajar Siswa Kelas XI SMA Negeri di Kabupaten Sambas Tahun 2015/2016. Historika: Journal of History Education Research, 16(1), 42-53.

Emda, A. (2018). Kedudukan Motivasi Belajar Siswa dalam Pembelajaran. Lantanida Journal, 5(2), 172-182.

Fathurrohman, M. (2017). Model-model Pembelajaran Inovatif. Yogyakarta: Ar-Ruzz Media.

Febriana, A. (2011). Penerapan Model Pembelajaran Kooperatif Tipe Make a Match Untuk 
Meningkatkan Kualitas Pembelajaran Ips Siswa Kelas V Sdn Kalibanteng Kidul 01 Kota Semarang. Kreatif: Jurnal Kependidikan Dasar, 1(2), 151-161.

Hamid, N. (2018). Pengaruh Model Pembelajaran Kooperatif Tipe Make a Match Terhadap Kreativitas, Motivasi, dan Hasil Belajar Biologi pada Materi Tumbuhan Lumut Kelas X SMA Negeri 2 Sarmi. Jurnal Ilmu Pendidikan Indonesia, 6(2), 39-46. Huda, M. (2013). Cooperative Learning. Yogyakarta: Pustaka Belajar.

Lestari, D. P. (2016). Peningkatan Aktivitas Belajar Siswa dalam Menggambar Peta Tematik Melalui Kegiatan Praktikum pada Pembelajaran Geografi di MA. Universitas Negeri Semarang.

Muchtar, S. Al. (2004). Pengembangan Berpikir dan Nilai dalam Pendidikan IPS. Bandung: Gelar Pustaka Mandiri.

Munandar, U. (2014). Pengembangan Kreativitas Anak Berbakat. Jakarta: Rineka Cipta.

Nurmanika, W., \& Rif'at, M. S. (2015). Upaya Menumbuhkan Kreativitas Belajar dengan Menggunakan Pembelajaran Kooperatif Tipe Make A Match. Jurnal Pendidikan Dasar, 3(1), 73-81.

Siska, Y. (2016). Konsep Dasar IPS untuk SD/MI (Andri Wicaksono, Ed.). Yogyakarta: Garudhawaca.

Sugiyono. (2015). Metode Penelitian Pendidikan. Bandung: Alfabeta.

Wahab, A. aziz. (2012). Metode dan Model-model Mengajar IPS (Ilmu Pengetahuan Sosial). Bandung: Alfabeta.

Yuliana, E. (2015). Pengembangan Soal Open Ended pada Pembelajaran Matematika untuk Mengidentifikasi Kemampuan Berfikir Kreatif Siswa. Prosiding Seminar Nasional Pendidikan Matematika (SNAPTIKA), 165-172. Palembang.

Zakiah, I., \& Kusmanto, H. (2017). Pengaruh Penerapan Model Pembelajaran Kooperatif Tipe Make a Match Terhadap Kreativitas Siswa Dalam Pembelajaran Matematika. Eduma : Mathematics Education Learning and Teaching, 6(1), 32. https://doi.org/10.24235/eduma.v6i1.1660 